\title{
Optimasi Proses Perlakuan Awal NaOH Tandan Kosong Kelapa Sawit untuk menjadi Bioetanol
}

\section{Optimization of NaOH Alkali Pretreatment of Oil Palm Empty Fruit Bunch for Bioethanol}

\author{
Muryanto $^{1}$, Yanni Sudiyani ${ }^{1}$ dan Haznan Abimanyu ${ }^{1}$ \\ ${ }^{1}$ Pusat Penelitian Kimia - LIPI, Kawasan Puspiptek Serpong Tangerang Selatan, 15314 \\ Corresponding author : muryanto@lipi.go.id
}

\author{
AR T I CLE INFO \\ Article history \\ Received date :22 December 2015 \\ Revised date : 12 May 2016 \\ Accepted date :10 June 2016 \\ Available online at: \\ http://kimia.lipi.go.id/inajac/index.php

\section{Kata kunci:} \\ Bioetanol, $\mathrm{NaOH}$, Perlakuan awal \\ kimia, TKKS, suhu, waktu

\section{Keywords:} \\ bioethanol, chemical pretreatment, \\ EFB, NaOH, temperature, time
}

\begin{abstract}
Abstrak
Bioetanol dari bahan baku limbah lignoselulosa menjadi energi alternatif yang mulai dikembangkan. Perlakuan awal merupakan tahap awal dari proses konversi lignoselulosa menjadi bioetanol. Perlakuan awal kimia $\mathrm{NaOH}$ dilakukan dengan memasukkan TKKS berukuran $3 \mathrm{~mm}$ dan larutan $\mathrm{NaOH} 10 \%$ pada reaktor bersuhu sedang dan tekanan 4 bar. Pada penelitian akan diketahui pengaruh suhu dan waktu proses pada perlakuan awal TKKS. Variasi suhu proses dimulai dari suhu 140,150 dan $160^{\circ} \mathrm{C}$, sedangkan variasi waktu proses dimulai dari 20, 30 dan 40 menit. Hasil perolehan biomassa tertinggi didapatkan pada proses perlakuan awal dengan suhu $140{ }^{\circ} \mathrm{C}, 20$ menit sebesar $42,83 \%$ (basis berat kering), delignifikasi tertinggi pada suhu $160{ }^{\circ} \mathrm{C}, 40$ menit yaitu sebesar 86,92\%. Namun kondisi optimal perlakuan awal TKKS untuk menghasilkan bioetanol tertinggi diperoleh pada suhu 150 ${ }^{\circ} \mathrm{C}, 30$ menit yaitu perolehan biomassa sebesar 35,97 \%, delignifikasi sebesar $76,74 \%$ dan yield etanol terhadap TKKS awal sebesar $15.17 \%$ (b/b).

\section{Abstract}

Bioethanol from lignocellulosic waste as an alternative energy began to be developed. Pretreatment is an early stage of the process of lignocellulose conversion into bioethanol. Chemical pretreatment using $\mathrm{NaOH}$ was done by inserting $3 \mathrm{~mm} \mathrm{EFB}$ and $10 \% \mathrm{NaOH}$ solution at the reactor in moderate temperature and 4 bars pressure. The effect of temperature and time on the pretreatment process was investigated. The variation of temperature process starts from 140,150 and $160^{\circ} \mathrm{C}$, during the time variation of the process starting from 20, 30 and 40 minutes. The highest of biomass recovery was obtained in the pretreatment process with temperature $140^{\circ} \mathrm{C}, 20$ minutes at $42.83 \%$ (dba). The highest delignification at $160^{\circ} \mathrm{C}$ temperature, 40 minutes was equal to $86.92 \%$. However, the optimal pretreatment conditions to produce the highest bioethanol from EFB obtained at $150{ }^{\circ} \mathrm{C}, 30$ minutes were the biomass recovery reached $35.97 \%$, delignification reached 76.74 $\%$, and ethanol yield from initial EFB reached $15,17 \%(w / w)$.
\end{abstract}

(C) 2016 Indonesian Journal of Applied Chemistry. This is an open access article under the CC BY-NC-SA license. 


\section{PENDAHULUAN}

Resiko pemanasan global dan berkurangnya cadangan energi fosil menyebabkan semakin berkembangnya produksi dan penggunaan bioetanol sebagai energi alternatif yang lebih ramah lingkungan. Bioetanol dari bahan baku limbah lignoselulosa menjadi sesuatu yang menarik sebagai energi alternatif. Limbah lignoselulosa mengandung selulosa yang tinggi dapat diubah menjadi etanol. Tandan kosong kelapa sawit (TKKS) merupakan limbah lignoselulosa yang cukup melimpah. Pada tahun 2014 perkebunan kelapa sawit di Indonesia mencapai 10,46 juta hektar dengan produksi CPO mencapai 29,34 juta ton. Setiap 1 ton CPO yang diproduksi menghasilkan limbah lignoselulosa mencapai 1,1 ton $^{[1]}$. TKKS mengandung selulosa, lignin, hemiselulosa, abu dan zat ektraktif lainnya ${ }^{[2]}$. Kandungan kimia TKKS pada umumnya adalah selulosa, hemiselulosa dan lignin. Selulosa sebagai fraksi terbesar yaitu sekitar $25-45 \%^{[2]}$ dalam lignoselulosa dapat dikonversi menjadi glukosa dengan menggunakan enzim selulase. Glukosa yang dihasilkan akan difermentasi menjadi etanol oleh Saccharomyces cerevisiae $^{[3]}$.

Proses produksi bioetanol dari TKKS secara garis besar dapat dikelompokkan menjadi 3 tahap. Tahap pertama adalah tahap perlakuan awal TKKS dengan tujuan untuk menghilangkan lignin, mengurangi kristalinitas selulosa, meningkatkan porositas dan mengubah TKKS menjadi pulp. Tahap kedua adalah tahap hidrolisa/sakarifikasi dan fermentasi yang bertujuan mengubah selulosa TKKS menjadi etanol, dan tahap terakhir adalah pemurnian untuk mendapatkan etanol dengan konsentrasi tinggi.

Perlakuan awal merupakan salah satu tahap yang mahal dalam proses konversi biomassa selulosa menjadi etanol ${ }^{[4]}$. Secara konvensional, perlakuan awal dapat dilakukan dengan proses biologi, kimia, fisika atau termal, dan setiap proses mempunyai keunggulan dan kelemahan. Perlakuan awal fisik umumnya berupa pemotongan, penghancuran, radiasi, dan sebagainya bertujuan untuk mengurangi ukuran lignoselulosa ${ }^{[5]}$. Perlakuan awal secara biologi tidak menggunakan bahan kimia, sehingga lebih ramah terhadap lingkungan. Namun kelemahannya adalah waktu proses yang lama, kebutuhan lahan yang luas dan pengkontrolan akan kontaminasi mikroba lain ${ }^{[6]}$. Perlakuan awal secara kimia dapat menggunakan asam dan alkali. Perlakuan awal secara alkali bertujuan untuk mengurangi kandungan lignin dalam lignoselulosa (delignifikasi). Perlakuan awal alkali mempunyai keuntungan dapat meningkatkan kandungan selulosa, menurunkan tingkat polimerisasi selulosa sehingga dapat meningkatkan kinerja enzim pada proses sakarifikasi $^{[7,8]}$. Proses perlakuan awal yang baik adalah yang dapat mengurangi penggunaan enzim yang harganya mahal ${ }^{[6]}$. Oleh karena itu, Cardona dan Sanchez ${ }^{[9]}$ menyatakan tahap tersebut merupakan tantangan utama pada konversi biomassa lignoselulosa menjadi etanol.

Perlakuan awal alkali banyak dilakukan menggunakan $\mathrm{NaOH}$, seperti yang dilakukan oleh Duangwang dan Sangwichien ${ }^{[10]}$ yang melakukan perlakuan awal pada TKKS menggunakan konsentrasi $\mathrm{NaOH}$ yang divariasikan. Proses perlakuan awal dengan $\mathrm{NaOH}$ memiliki kesamaan proses dengan proses kraft pada pembuatan kertas. Perlakuan awal $\mathrm{NaOH}$ juga dapat dipadukan dengan proses perlakukan awal lainnya ${ }^{[11]}$. Choi et $a l .{ }^{[12]}$ melakukan pretreatment $\mathrm{NaOH}$ yang dipadukan dengan steam. Perlakuan awal kimia dengan $\mathrm{NaOH}$ umumnya terjadi pada suhu rendah, namun mempunyai kelemahan waktu proses yang lama yaitu diatas 1 jam bahkan hampir $24 \mathrm{jam}^{[13,14]}$. Oleh karena itu pada penelitian ini digunakan perlakuan awal kimia pada suhu sedang diatas $100{ }^{\circ} \mathrm{C}$ dengan waktu proses yang lebih pendek yaitu 20-40 menit.

Makalah ini akan membahas tentang variasi kondisi proses perlakuan awal kimia menggunakan $\mathrm{NaOH}$ pada TKKS dan mengetahui pengaruh suhu dan waktu proses perlakuan awal yang optimum sebagai tahap awal untuk proses pembuatan bioetanol dari lignoselulosa.

\section{BAHAN DAN METODA}

2.1. Bahan 
Pada penelitian ini tandan kosong kelapa sawit (TKKS) yang digunakan diperoleh dari Perkebunan Kelapa Sawit Musi Banyuasin, Palembang, Indonesia. Semua bahan kimia dan reagen yang digunakan pada penelitian ini (kecuali $\mathrm{NaOH}$ ) diperoleh dari Merck dan Sigma, sedangkan $\mathrm{NaOH}$ teknis merupakan grade industri. Pada penelitian ini digunakan enzim selulase komersial Cellic CTech2 dan HTech2 yang diperoleh dari NOVOzymes Aktifitas enzim selulase ini sebesar 140 FPU/ml. 1 FPU sebanding dengan 1 mol glukosa yang terbentuk dari selulosa per $1 \mathrm{ml}$ enzim. Saccharomyces cerevisiae yang digunakan dalam bentuk ragi instan komersial.

\subsection{Metoda}

\subsubsection{Perlakuan awal fisik}

Proses perlakuan awal dilakukan secara fisik dengan mengubah TKKS menjadi serat, dikeringkan kemudian dicacah menjadi berukuran kurang lebih $3 \mathrm{~mm}$.

\subsubsection{Perlakuan awal kimia}

Proses perlakuan awal kimia dengan $\mathrm{NaOH}$ dilakukan pada reaktor chemical explosive (KIMEKS). Sebanyak 500 gram biomassa TKKS dicampur dengan larutan $\mathrm{NaOH}$ konsentrasi $10 \%$ sebanyak $2500 \mathrm{~mL}$. Temperatur yang digunakan pada penelitian ini adalah 140,150 dan $160{ }^{\circ} \mathrm{C}$, sedangkan waktu proses adalah 20, 30 dan 40 menit. Setelah proses selesai, campuran yang terdiri dari biomassa lignoselulosa dan $\mathrm{NaOH}$ disaring untuk memisahkan padatan TKKS dan cairan lindi hitam yang mengandung lignin. TKKS hasil penyaringan dicuci hingga $\mathrm{pH}$ netral, kemudian dikeringkan dalam oven pada suhu $50{ }^{\circ} \mathrm{C}$ selama 24 jam untuk selanjutnya digunakan pada proses sakarifikasi dan fermentasi serentak (Simultaneous Saccharification and Fermentation/SSF).

\subsubsection{Sakarifikasi dan Fermentasi Serentak (SSF)}

TKKS yang telah dilakukan perlakuan awal sebanyak $15 \mathrm{~g}$ dicampurkan ke dalam $0.05 \mathrm{M}$ bufer sitrat pada erlenmeyer berukuran $250 \mathrm{ml}$. Semua media disterilisasi dengan menggunakan autoclave (Daihan Labtech Co., Ltd., Korea) pada suhu $121^{\circ} \mathrm{C}$. Kemudian enzim, dan Saccharomyces cerevisiae bubuk sebanyak $1 \%(\mathrm{~b} / \mathrm{v})$ dimasukkan ke dalam media secara aseptis untuk menghindari kontaminasi. Total volume media yang digunakan pada proses SSF adalah $100 \mathrm{ml}$. Proses SSF dilakukan pada suhu $32^{\circ} \mathrm{C}$, pada shaker inkubator (Dasol Scientific DS-310C2, Korea) dengan kecepatan putar $150 \mathrm{rpm}$. Enzim yang ditambahkan pada penelitian ini sebesar 40 FPU/g berat kering TKKS yang digunakan. Proses SSF dilakukan selama 96 jam dengan interval waktu sampling tiap 24 jam.

\subsubsection{Analisa Komponen}

Analisa komponen TKKS dilakukan dengan metode NREL (National Renewable Energy Laboratory). Sebanyak 0.3 gram biomassa $(<1 \mathrm{~mm})$ dihidrolisis dengan penambahan $3 \mathrm{~mL} \mathrm{H}_{2} \mathrm{SO}_{4} 72 \%$ dalam tabung reaksi. Selanjutnya campuran biomass diinkubasi pada suhu $30^{\circ} \mathrm{C}$ selama \pm 1 jam dan dihomogenkan setiap 10 menit sehingga diperoleh campuran berwarna hitam. Pada botol schoot disiapkan $42 \mathrm{~mL}$ destilat water, endapan hitam pada tabung reaksi di tuang kedalam botol schoot dan dibilas dengan air suling beberapa kali dan dituang hingga volume 84 mL. Untuk hidrolisis yang kedua, sampel dimasukkan ke dalam autoklaf pada suhu 121 ${ }^{\circ} \mathrm{C}$ selama \pm 1 jam. Kemudian sampel didiamkan pada suhu ruang $\pm 24^{\circ} \mathrm{C}$, diperoleh cairan bening dan endapan hitam.

\section{Penentuan Kadar Abu}

Kertas saring kosong ditimbang (Sartorius BS 224S, England), sampel yang dihasilkan dari proses sebelumnya, dituangkan hingga tidak ada yang tersisa ke sistem vakum. Kertas saring dikeringkan dengan moisture analyzer (Ohaus MB45, China) dan ditimbang bobotnya. Kertas saring dipindahkan pada cawan crucible kemudian di masukkan kedalam tungku pada 
suhu $600{ }^{\circ} \mathrm{C}$ selama \pm 3 jam. Selanjutnya cawan didinginkan dalam desikator \pm 15 menit kemudian ditimbang bobot kertassaring + cawan dan bobot cawan kosong.

\section{Penentuan Lignin}

Lignin tidak larut dihitung berdasarkan perbandingan berat sampel setelah hidrolisis dikurangi kadar abu dengan berat sampel awal. Lignin terlarut dihitung dengan metode spektofotometri. Sampel yang diperoleh dari proses fitrasi ditambahkan $3 \mathrm{~mL} \mathrm{H}_{2} \mathrm{SO}_{4} 4 \%$. Campuran sampel kemudian diukur absorbansinya dengan menggunakan spektrofotometer UV (Optizen, Korea) dengan panjang gelombang $205 \mathrm{~nm}$.

\section{Penentuan Selulosa dan Hemiselulosa}

Sampel hasil filtrasi dipipet sebanyak 3 $\mathrm{mL}$, lalu ditambahkan $\mathrm{CaCO}_{3}$ hingga $\mathrm{pH}$ netral. kemudian disaring dan diuji kadar glukosa dan xylosa dengan menggunakan HPLC (Waters e2695, USA). Kolom yang digunakan pada proses ini yaitu Aminex HPX-87C column, 250 x $4 \mathrm{~mm}$ pada suhu $65{ }^{\circ} \mathrm{C}$ dan $\mathrm{H}_{2} \mathrm{O}$ sebagai eluennya. Persentase selulosa dan hemiselulosa dihitung berdasarkan pada konsentrasi glukosa dan xilosa menggunakan koreksi anhidro 0,88 untuk xilosa dan koreksi 0.9 untuk glukosa ${ }^{(15)}$.

Sampling proses SSF dilakukan tiap interval 24 jam. Sampel diambil dari erlenmeyer dan disimpan di dalam freezer. Sampel dianalisa kandungan glukosa dan etanol menggunakan HPLC (Waters e2695, USA), Kolom Aminex HPX-87C (Bio-Rad, Richmond, CA, USA), RI Detector (Waters, 2414), suhu kolom $65{ }^{\circ} \mathrm{C}$, suhu detektor $40^{\circ} \mathrm{C}$, air sebagai eluent dengan laju alir $0.6 \mathrm{l} / \mathrm{min}$.

\section{HASIL DAN PEMBAHASAN}

Komposisi selulosa, hemiselulosa dan lignin TKKS sebelum dilakukan proses perlakuan awal dapat dilihat pada Tabel 1 . Dapat terlihat bahwa TKKS berpotensi dijadikan bahan baku untuk proses pembuatan bioetanol karena mengandung selulosa yang cukup tinggi. Namun kadar lignin yang cukup tinggi yaitu $26,53 \%$ membuat TKKS harus dilakukan proses perlakuan awal terlebih dahulu.

Proses perlakuan awal TKKS dimulai dengan perlakuan fisik yang bertujuan untuk mengurangi ukuran lignoselulosa sehingga mudah diproses lebih lanjut. Selanjutnya proses perlakuan awal kimia dilakukan dengan mencampurkan larutan alkali $\mathrm{NaOH} 10 \%$ dan TKKS pada reaktor chemical explosive (KIMEKS) dengan variasi suhu yang berbeda yaitu 140,150 , dan $160^{\circ} \mathrm{C}$. Penggunaan bahan kimia $\mathrm{NaOH}$ bertujuan memisahkan lignin yang melapisi selulosa pada TKKS, dikarenakan $\mathrm{NaOH}$ mampu mengikat lignin atau lilin yang menutupi selulosa. Mekanisme yang terjadi adalah saponifikasi ikatan-ikatan ester antar molekul yang mengikat silang xilan dan komponen-komponen lainnya, misalnya lignin dan hemiselulosa lainnya ${ }^{(16)}$.

Tabel 1. Komposisi Kimia TKKS Sebelum Perlakuan Awal Kimia

\begin{tabular}{clr}
\hline No & \multicolumn{1}{c}{ Komponen } & \multicolumn{1}{l}{$\%$} \\
\hline 1 & Lignin & 26,53 \\
2 & Selulosa & 36,59 \\
3 & Hemiselulosa & 24,97 \\
4 & Abu & 1,79 \\
\hline
\end{tabular}

\subsection{Perolehan Biomassa}

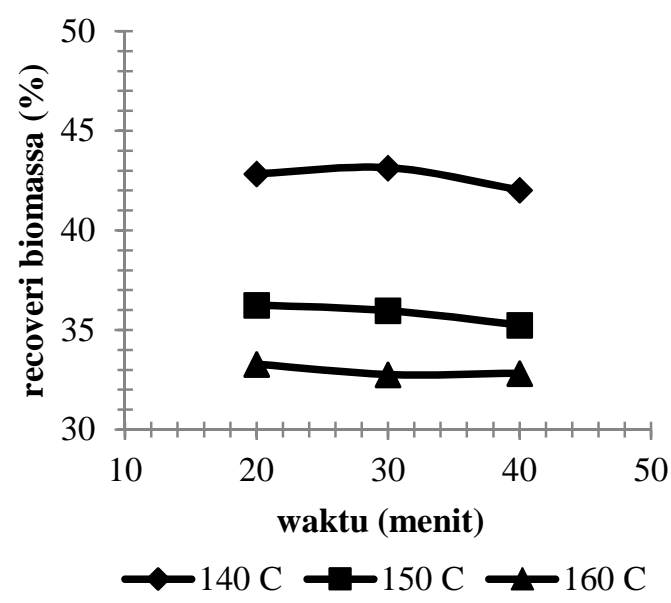

Gambar 1. Perolehan kembali biomassa setelah perlakuan awal 
TKKS yang telah mengalami proses perlakuan awal akan mengalami mengalami perubahan komposisi. Proses perlakuan awal kimia dengan alkali bertujuan untuk mengurangi kandungan lignin, senyawa grup asetil, dan melarutkan sedikit hemiselulosa. Proses perlakuan kimia dengan $\mathrm{NaOH}$ dapat juga menyebabkan terjadinya pengembangan (swelling) pada struktur selulosa ${ }^{(4)}$. Pengurangan lignin, hemiselulosa dan senyawa kimia lainnya akan menyebabkan berkurangnya massa TKKS yang dihasilkan. Banyaknya massa TKKS yang dihasilkan dari proses perlakuan awal ditunjukkan pada Gambar 1.

Secara umum TKKS yang telah dilakukan perlakuan awal akan kehilangan hampir setengah dari massa awalnya. Waktu proses perlakuan awal berpengaruh terhadap perolehan massa TKKS, semakin lama waktu proses akan semakin sedikit perolehan massa TKKS. Begitu juga dengan perlakuan suhu proses. Semakin tinggi suhu proses perlakuan awal akan menyebabkan perolehan massa TKKS semakin sedikit. Hal ini disebabkan oleh semakin banyaknya lignin dan hemiselulosa yang terlarut dalam lindi hitam. Perolehan massa terbanyak terjadi pada waktu 20 menit dengan suhu proses $140{ }^{\circ} \mathrm{C}$ yaitu sekitar $42.83 \%$. Hasil ini sejalan dengan hasil penelitian yang dilakukan oleh Choi et al. ${ }^{(12)}$ yang melakukan perlakuan awal kimia dengan $\mathrm{NaOH}$ pada TKKS maupun yang dilakukan oleh Kang et al. ${ }^{(17)}$ pada Miscanthus dengan hasil perolehan biomassa sebesar $46.1 \%$ hingga $72.7 \%$.

Tabel 2. Komposisi Kimia TKKS Setelah Perlakuan Awal Kimia

\begin{tabular}{cccccc}
\hline \multicolumn{2}{c}{ Variasi } & & & Hemi & Lignin \\
$\mathbf{t}$ & $\mathbf{T}$ & $\begin{array}{c}\text { Selulosa } \\
{[\%]}\end{array}$ & $\begin{array}{c}\text { [\%] } \\
\text { selulosa } \\
{[\text { \% }]}\end{array}$ & $\begin{array}{c}\text { Abu } \\
{[\%]}\end{array}$ \\
\hline \multirow{2}{*}{20} & 140 & 17,32 & 67,80 & 8,84 & 1,07 \\
& 150 & 6,11 & 70,59 & 12,34 & 2,11 \\
& 160 & 4,56 & 73,61 & 13,16 & 1,86 \\
& & & & & \\
\multirow{2}{*}{30} & 140 & 13,95 & 67,59 & 13,67 & 0,79 \\
& 150 & 6,17 & 72,53 & 14,22 & 2,12 \\
& & & & & \\
\hline
\end{tabular}

Accreditation number : 540/AU1/P2MI LIPI/06/2013

\begin{tabular}{cccccc} 
& 160 & 4,57 & 78,87 & 10,91 & 2,12 \\
& & & & & \\
40 & 140 & 13,45 & 71,73 & 8,37 & 1,23 \\
& 150 & 6,25 & 75,67 & 12,25 & 1,55 \\
& 160 & 3,47 & 80,97 & 9,37 & 1,66 \\
\hline
\end{tabular}

Tabel 2, menunjukkan terjadinya peningkatan kandungan selulosa yang terdapat pada TKKS yang telah dilakukan proses perlakuan awal. Kandungan selulosa pada TKKS mengalami peningkatan dari $30 \%$ menjadi 60-80 \%. Selain itu terjadi pengurangan pada kandungan lignin dan hemiselulosa. Perlakuan awal dengan $\mathrm{NaOH}$ juga dapat melarutkan hemiselulosa pada TKKS seperti yang telah dilakukan oleh Duangwang dan Sangwichien ${ }^{(10)}$ maupun pada lignoselulosa lain seperti batang pohon kacang kedelai ${ }^{(18)}$.

\subsection{Delignifikasi}

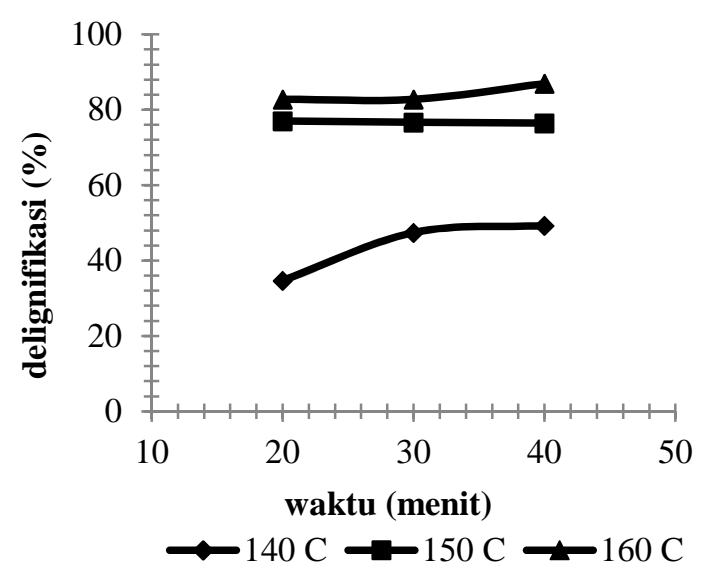

Gambar 2. Delignifikasi TKKS

Gambar 2, menunjukkan grafik delignifikasi yang terjadi pada TKKS, semakin lama waktu proses, semakin tinggi delignifikasi TKKS. Begitu pula dengan semakin tinggi suhu proses, semakin tinggi juga delignifikasi yang terjadi. Delignifikasi tertinggi diperoleh proses perlakukan awal dengan suhu $160{ }^{\circ} \mathrm{C}, 40$ menit yaitu sebesar $86.92 \%$. $\mathrm{NaOH}$ merupakan agen pendelignifikasi yang paling baik dibandingkan bahan kimia lainnya seperti amoniak, $\mathrm{NaClO}_{2}$ dan $\mathrm{H}_{2} \mathrm{O}_{2}{ }^{(11)}$. Sjostrom ${ }^{(19)}$ menyatakan bahwa terdapat 3 (tiga) fasa pelarutan lignin yang terjadi yaitu fasa delignifikasi awal, 
delignifikasi sebagian dan delignifikasi akhir. Accreditation number : 540/AUI/P2MI LIPI/06/2013

Pada delignifikasi awal yang terjadi pada suhu rendah umunya dikontrol oleh difusi. Sedangkan pada tahap berikutnya pada delignifikasi fasa kedua dikontrol oleh reaksireaksi kimia dimana temperatur yang terjadi diatas $140{ }^{\circ} \mathrm{C}$. Pada fasa ini laju reaksi mengalami kenaikan seiring dengan kenaikan suhu. Delignifikasi TKKS bermanfaat juga untuk meningkatkan kemampuan kinerja enzim selulase pada proses sakarifikasi. Millet et al. ${ }^{(20)}$ dalam Kang et al. ${ }^{(17)}$ melaporkan bahwa kinerja enzim meningkat hingga $14 \%$ sampai $55 \%$ pada kayu keras ketika kandungan lignin berkurang dari $24-55 \%$ menjadi $20 \%$.

\subsection{Lindi Hitam}

Pada proses perlakuan awal kimia, selain diperoleh padatan TKKS juga diperoleh lindi hitam sebagai residu proses. Tabel 3. menunjukan volume lindi hitam hasil pulping/pemasakan dan $\mathrm{pH}$ lindi hitam. Lindi hitam mengandung lignin, hemiselulosa dan sisa $\mathrm{NaOH}$ dari proses. Lindi hitam berbau tidak sedap karena mengandung senyawa kimia seperti metal merkaptan, dimetil sulfida $\left(\left(\mathrm{CH}_{3}\right)_{2} \mathrm{~S}\right)$ dan dimetil disulfida $\left(\mathrm{CH}_{3}-\mathrm{S}-\mathrm{S}-\mathrm{CH}_{3}\right)$. Gas-gas ini terbentuk oleh reaksi pemutusan ikatan metil aril eter pada salah satu unit penyusun lignin ${ }^{(21)}$.

Tabel 3. Lindi Hitam Residu Perlakuan Awal

\begin{tabular}{cccc}
\hline \multicolumn{2}{c}{ Variasi } & Vol. lindi hitam & $\mathbf{p H}$ \\
$\mathbf{t}$ & $\mathbf{T}$ & $(\mathbf{m L})$ & lindi hitam \\
$(\mathbf{m n t})$ & $\left({ }^{\circ} \mathbf{C}\right)$ & & \\
\hline \multirow{2}{*}{20} & 140 & 1650 & 13.67 \\
& 150 & 1640 & 13.33 \\
& 160 & 1750 & 13.77 \\
\multirow{2}{*}{30} & 140 & 1740 & \\
& 150 & 1800 & 13.70 \\
& 160 & 1850 & 13.47 \\
& & &
\end{tabular}

150

2000

160

2340

13.63

13.26

Dari hasil percobaan seperti ditunjukkan pada Tabel 3, menunjukkan bahwa suhu memberikan pengaruh yang sangat signifikan terhadap volume lindi hitam yang dihasilkan. Setiap kenaikan suhu maka volume lindi hitam yang didapat akan semakin bertambah. Terbukti pada varisi waktu volume lindi hitam yang paling besar terbentuk pada suhu operasi 160 ${ }^{\circ} \mathrm{C}$ yaitu 2,34 liter. Menurut G. Bernasconi, et $a l .^{(22)}$, salah satu faktor yang sangat berpengaruh untuk mencapai untuk kerja ekstraksi atau kecepatan ekstraksi yang tinggi pada ekstraksi padat-cair adalah suhu. Lindi hitam yang terbentuk mempunyai $\mathrm{pH}$ diatas 13 . Hal ini menunjukkan masih tingginya kadar $\mathrm{NaOH}$ dalam lindi hitam. Kandungan $\mathrm{NaOH}$ dalam lindi hitam ini berpotensi untuk dipakai kembali dalam proses perlakuan awal dengan cara pemakaian kembali (reuse).

\subsection{Sakarifikasi dan Fermentasi Serentak (SSF)}

Proses sakarifikasi dan fermentasi serentak dari TKKS yang telah mengalami perlakuan awal dilakukan dalam kondisi aerob. Enzim selulase kompleks berperan dalam proses sakarifikasi yaitu memecah rantai panjang selulosa menjadi monomer glukosa, yang akan secara simultan dikonversi menjadi etanol oleh $S$. cerevisiae. Proses fermentasi umumnya menggunakan $S$. cerevisiae karena kemampuannya menghasilkan etanol dari glukosa dengan konsentrasi tinggi. Namun $S$. cerevisiae tidak dapat mengubah xylosa menjadi etanol. Fermentasi xilosa dapat dilakukan dengan menggunakan ragi jenis lain seperti Pichia stipitis ${ }^{(23)}$. Proses SSF lebih menguntungkan karena dapat mengurangi efek penghambatan proses yang disebabkan akumulasi monosakarida dan disakarida, meningkatkan laju sakarifikasi dan fermentasi sehingga menghasilkan etanol yang lebih tinggi, dan mengurangi waktu proses dan biaya $\operatorname{produksi}^{(24)}$. 
Gambar 3. menunjukkan hasil produksi bioetanol selama 72 jam dari TKKS yang telah dilakukan perlakuan awal pada waktu proses 20 menit dengan variasi suhu. Etanol yang terbentuk dari hasil SSF memiliki kecenderungan yang sama, yaitu semakin lama proses fermentasi etanol yang terbentuk semakin meningkat. Hal ini menunjukkan terjadinya konversi selulosa oleh enzim selulase menjadi glukosa kemudian diubah menjadi etanol. Etanol tertinggi diperoleh pada TKKS perlakuan awal dengan suhu $160^{\circ} \mathrm{C}$ yaitu sebesar 7,25 \%(b/b). Hal ini sesuai dengan Badger $^{(3)}$ yang menunjukan semakin tinggi selulosa dalam subtrat, maka semakin tinggi etanol yang dihasilkan. Hasil penellitian ini lebih tinggi dibandingkan hasil yang diperoleh Muryanto et al. ${ }^{(25)}$ pada proses SSF TKKS menggunakan Rhizopus oryzae yaitu 3,38\%. Residu hasil fermentasi pada proses perlakuan awal variasi suhu menunjukkan semakin tinggi suhu proses perlakuan awal, residu yang dihasilkan semakin sedikit (data tidak ditunjukkan). Hal ini disebabkan oleh semakin berkurangnya kadar lignin dalam bahan TKKS sehingga semakin sedikit sisa TKKS yang terdapat pada akhir proses SSF.

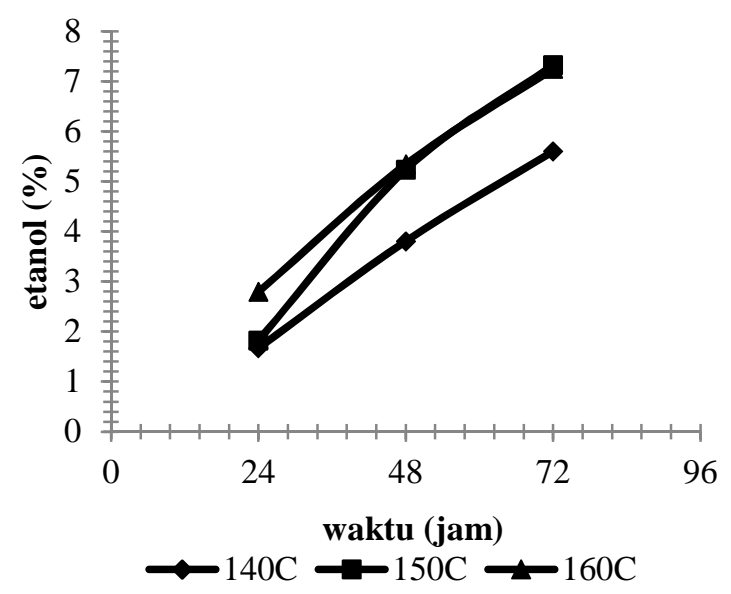

Gambar 3. Proses SSF TKKS hasil perlakukan awal $\mathrm{t}=20$ menit selama 72 jam

Yield etanol yang terbentuk terhadap TKKS awal sebelum dilakukan proses perlakuan awal ditunjukkan pada Gambar 4. Yield etanol ini menunjukkan berapa banyak gram etanol yang dihasilkan tiap gram TKKS yang digunakan sebagai subtrat.
Walaupun dari Gambar 3. diperoleh suhu $160{ }^{\circ} \mathrm{C}$ memberikan etanol tertinggi pada proses SSF, namun yield etanol tertinggi tidak terjadi pada suhu $160{ }^{\circ} \mathrm{C}$ karena hanya mencapai 14,24 $\%$. Hal ini dikarenakan perolehan biomassa pada suhu $160{ }^{\circ} \mathrm{C}$ lebih kecil dibandingkan suhu proses yang lain seperti yang terlihat pada Gambar 1. Yield etanol tertinggi terjadi pada TKKS dengan perlakuan awal pada suhu $150{ }^{\circ} \mathrm{C}$ dengan waktu proses 30 menit yaitu sebesar $15.17 \%$.

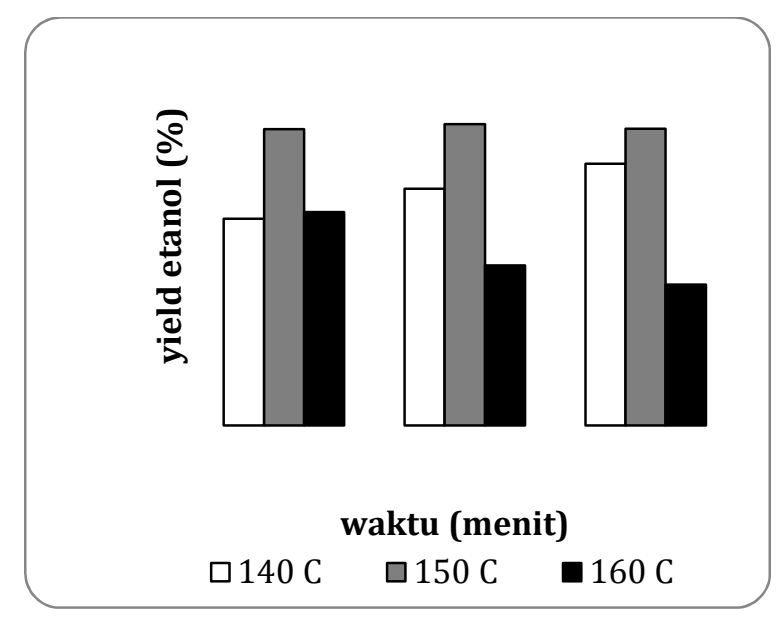

Gambar 4. Yield Etanol terhadap TKKS Awal

\section{KESIMPULAN}

Berdasarkan hasil penelitian dapat disimpulkan bahwa suhu dan waktu proses memberikan pengaruh yang signifikan terhadap hasil perlakuan awal. Semakin lama waktu proses semakin tinggi delignifikasi yang dihasilkan, namun semakin sedikit biomassa yang dihasilkan. Semakin tinggi suhu proses dihasilkan delignifikasi yang semakin tinggi Kondisi optimal pada proses perlakuan awal adalah pada suhu $150^{\circ} \mathrm{C}$ dan waktu 30 menit. Pada kondisi ini delignifikasi TKKS mencapai $76,74 \%$, dan perolehan biomassa sebesar $35,97 \%$, dengan konversi etanol terhadap TKKS sebesar $15,17 \%(\mathrm{~b} / \mathrm{b})$.

\section{UCAPAN TERIMA KASIH}

Ucapan terima kasih penulis sampaikan kepada Hendris Hendarsyah dan Irni Fitria yang telah membantu penelitian ini. Pelaksanaan 
penelitian ini didanai oleh Pusat Penelitian Kimia LIPI melalui Program Prioritas Nasional (PN) Bioenergi 2014.

\section{DAFTAR PUSTAKA}

[1] E.I Wiloso, E. Triwahyuni, V. Barlianti, Muryanto. Review potensi pengembangan bioetanol dari biomasa lignoselulosa kelapa sawit. Prosiding Seminar Nasional Kimia, Surabaya. Indonesia, 2010.

[2] Y. Sudiyani. Utilization of biomass waste empty fruit bunch fiber of palm oil for bioethanol production, Research Workshop on Sustainable Biofuel, 2009. hal 1-15.

[3] P. C. Badger. Ethanol from cellulose: A general review. In: J, Janick and A, Whipkey (eds,). Trends in new crops and new uses, Alexandria VA: ASHS Press. 2002. 17-21.

[4] N. Mossier, D. Wyman, B. Dale, R. Elander, Y.Y. Lee, M. Holtzapple, M. Ladish. Features of promosing technologies for pretreatment of lignocellulosic biomass. Bioresource Technology; 96(6): 673-686 (2005).

[5] M. Y. Harun, A.B.D. Radiah, Z.Z. Abidin, R. Yunus R. Effect of physical pretreatment on dilute acid hydrolysis of water hyacinth (Eichhornia crassipes). Bioresource Technology; 102:5193-5199 (2011).

[6] C.E. Wyman, B.E. Dale, R.T. Elander, M. Holtzapple, M.R. Ladisch, and Y.Y. Lee. Coordinated development of leading biomass pretreatment technologies. Bioresource Technology 96(18): 1959-1966 (2005).

[7] S. Zhu, Y. Wu, Z. Yu, Q. Chen, G. Wu, F. Yu, C. Wang, S. Jin. Microwave-assisted alkali pretreatment of wheat straw and its enzymatic hydrolysis. Process Biochemistry. 94 (3):437-442 (2006).

[8] S. Zhu, Y. Wu, Z. Yu, X. Zhang, C. Wang,F. Yu, S. Jin. Production of ethanol from microwave-assisted alkali pretreated

\section{Accreditation number : 540/AU1/P2MI LIPI/06/2013}

wheat straw. Process Biochemistry 41:896-873 (2006).

[9] C.A. Cardona dan O.J. Sanchez. Fuel ethanol production: Process design trends and integration opportunities. Bioresource Technology. 98: 2415-2457 (2007).

[10] S. Duangwang dan C. Sangwichien. Optimizing Alkali Pretreatment of Oil Palm Empty Fruit Bunch for Ethanol Production by Application of Response Surface Methodology. Advanced Material Research vol 622-623. (2013).

[11] B. N. Adela, A.B. Nasrin, S.K. Loh, Y.M. Choo. Bioethanol Production by Fermentation of Oil Palm Empty Fruit Bunches Pretreated with Combined Chemicals. Journal of Applied Environmental and Biological Sciences 4(10): 234-242. (2014).

[12] W.I. Choi, J.Y. Park, J.P. Lee, Y.K. Oh, Y.C Park, J.S. Kim, J.M. Park, C.H. Kim, J.S. Lee. Optimization of $\mathrm{NaOH}-$ catalyzed Steam Pretreatment of Empty Fruit Bunch. Biotechnology for Biofuel. 6:170, (2013).

[13] M.J. Taherjadeh, K. Karimi. Pretreatment of Lignocellulosic Wastes to Improve Ethanol and Biogas Production : A Review. International Journal of Molecular Sciences. 9 : 1621-1651 (2008).

[14] V.B. Agbor, N. Cicek, R. Sparling, A. Berlin,D.B. Levin. Biomass pretreatment: fundamentals toward application. Biotechnol Advances 29:675-685 (2011).

[15] B. Sluiter, R. Hames, C. Ruiz, J. Scarlata, D. Sluiter, M. Templeton, D. Crocker. Determination of structural carbohydrates and lignin in biomass. Technical report NREL/TP-510-42618. (2011).

[16] Y. Sun, J. Cheng. Hydrolysis of lignocellulosic materials for ethanol production: a review. Bioresource Technology. 83, 1-1. (2002).

[17] K.E. Kang, M. Han, S.K. Moon, H.W. Kang, Y. Kim, Y.L. Cha, G.W. Choi. Optimization of alkali-extrusion 
pretreatment with twin-screw for bioethanol production from Miscanthus. Fuel 109;520-526 (2013).

[18] C. Wan, Y. Zhou, Y. Li. Liquid hot water and alkaline pretreatment of soybean straw for improving cellulose digestibility. Bioresource Technology 102:6254-9 (2011)

[19] E. Sjostrom. Kimia Kayu, Dasar-dasar dan Penggunaan Edisi Kedua. Yogyakarta: UGM-Press. 1995.

[20] M.A. Millet, A.J. Baker, L.D. Scatter. Physical and chemical pretreatment for enhancing cellulose. Applied Microbiol Biotechnology 1976;29:462-8 (1976)

[21] J.J. Gilligan. The Organic Chemicals Industries. dalam J.L. Pyle. Chemistry and the Technological Backlash. PrenticeHall, Inc., New Jersey. 1974.

[22] G. Bernasconi. Teknologi Kimia. Edisi pertama. Jakarta. PT. Pradaya Paramita. 1995.

[23] S. Watanabe, A.A. Saleh, S.P. Pack, N. Annaluru, T. Kodaki, K. Makino. Ethanol production from xylose by recombinant Saccharomyces cerevisiae expressing protein engineered NADH-preferring xylose reductase from Pichia stipitis. Microbiology, 153, 3044-3054. (2007).

[24] B. Jin,, H. J. van Leeuwen, B. Patel, H. Doelle,Q. Yu. Production of fungal protein and glucoamylase by Rhizopus oligosporus from starch processing wastewater, Process Biochemistry., 34: 59-65. (1999).

[25] Muryanto, M. Sahlan, Y. Sudiyani. Simultaneous Saccharification and Fermentation of Oil Palm Empty Fruit Bunch for Bioethanol Production by Rhizopus oryzae. International Journal of Environment and Bioenergy, 3(2): 111120 (2012). 
J.Kim.Terap.Indones., 18(1),

pp. 27-35, June 2016
p-ISSN: 0853-2788, e-ISSN: 2527-7669

Accreditation number : 540/AU1/P2MI LIPI/06/2013

Halaman ini sengaja dikosongkan

This page intentionally left blank

36 | "Optimasi Proses Perlakuan Awal ...": Muryanto, Y. Sudiyani, H. Abimanyu 